\title{
DESIGN AND DEVELOPMENT OF SOLAR STILL FOR EFFECTIVENESS IN ELIMINATING MICROBIAL CONTAMINATION AND SALT IN MUBI, ADAMAWA STATE, NIGERIA
}

\author{
D. W. Medugu*, and D. I. Malgwi** \\ *Department of Physics, Adamawa State University, Mubi, Nigeria \\ ** Department of Physics, University of Maiduguri, Maiduguri, Nigeria
}

(Submitted: 8 August, 2006; Accepted: 20 December, 2006)

\begin{abstract}
Solar still for the production of clean quality water fit for human consumption and other hygienic uses has been designed and developed. The design and operation, which is based on energy and environmental physics concept of rainwater-evaporation and condensation process, is simple, straightforward and has low maintenance cost. Twenty-four water samples were collected from various boreholes in Mubi, Adamawa State, Nigeria, in sterile bottles. Enumerations of aerobic bacteria by aerobic plate count and coli form by multiple-tube fermentation technique have been carried out. Results showed that heavily contaminated samples with an average microbial load of $2.57 \times 10^{4} \mathrm{cfu} / \mathrm{ml}$; a positive $100 \%$ distribution of coli form bacteria; and an input average of $266.7 \mathrm{mg} / \mathrm{l}$ of $\mathrm{CaCO}_{3}$ were completely eliminated producing up to 9 litres of pure water, with an average $\mathrm{pH}$ value of 9.13 per day in temperate climate. The water does not acquire the 'flat' taste of commercially distilled water since it is not boiled. This study is therefore an application of physics for the production of distilled water from contaminated water for both human health protection and environmental sustainability.
\end{abstract}

Key words: Solar still, portable water, health protection.

\section{Introduction}

Portable water may be described as water fit for human consumption. Since time immemorial, the portability of water stood out to be the clear definition of water quality (Walter, 1987). However, a large fraction of the World's population, about 1.1 billion people, do not have access to improved or microbiologically safe sources of water for drinking and other essential purposes (WHO, 2000). Consumption of unsafe water continues to be one of the major causes of the 2.2 million diarrheal disease deaths occurring annually, mostly in children under the age of five (WHO, 2000). During the year 1971 to 1980 alone, 315 outbreaks of water borne diseases in USA resulted in 78,000 illness in persons who drank water contaminated with pathogenic microorganism and chemicals (Gunnison, 1985).

Current estimation of the people consuming microbiologically unsafe water is probably low. This is because the assumptions about the safety or quality of water based on its source, extent of treatment or consumer handling do not take into consideration several well-documented problems. One of the problems is that protected or improved sources, such as boreholes and treated urban supplies, can still be contaminated such that microbially unsafe water is delivered. In some cities in Nigeria, the water systems draw unsafe water from unprotected or contaminated sources and deliver it to consumers with no or inadequate treatment. Yet, these water systems are classified or categorized as improved or safe. Another problem contributing to the underestimation of the population served by unsafe water is contamination of water during distribution whether water is piped or carried into the home. Many communities have protected improved water supplies and treated water that is microbiologically safe when collected, or when it leaves a treatment plant. However, substandard 
water distribution systems, intermittent water pressure due to power outages and other disruption, and illegal connections to the distribution system often lead to the introduction of fecal contamination and therefore, microbiologically contaminated water at the consumer's tap or collection point (Sobsey, 2002).

A further problem is that water collected for domestic use often becomes re-contaminated or further contaminated by unsafe consumer storage and handling practices at the household level. Many of the world's people continue to obtain their water on a daily or frequent basis from any available source and either carried it or otherwise have it delivered to the home for personal use. Typically, this water is not treated or otherwise protected from subsequent contamination during use. Such household water is at risk of being contaminated by various pathogenic viruses, bacteria and parasites associated with fecal wastes and other sources (Sanyaolu et al, 2002). Knowledge of solar energy and environmental physics plays important role in providing portable water in this modern world for health protection and environmental sustainability (Malgwi, 2006). The need for solar distillation is an overlooked solution to meeting portable water needs around the globe for reducing the risk of diarrheal disease and death in populations in all ages (Garba et al, 1999). The basic principles of solar water distillations are simple, yet effective, as distillation replicates the way nature purifies water (Cooper, 1969). The sun's energy heats water to the point of evaporation (Frohlich and Brusa, 1981; Garba et al, 1999). As the water evaporates, purified water vapour rises, condensing on the glass surface for collection (Garba et al, 1999; Smith and Gattlieb, 1974). This process removes impurities such as salts and heavy metals, as well as microbiological organism (Cooper, 1969; Garba et al, 1999). The end result is water even cleaner than pure rainwater, which aside from human consumption can be used in hospitals, laboratories and for batteries (Garba et al, 1999; Uwah et al, 2004).

This study is therefore aimed at using energy and environmental physics concept of rainwater evaporation and condensation process to design and develop a simple solar still for the production of clean quality water fit for human consumption and other hygienic uses.

\section{Study Area and Justification}

Mubi, which lies on latitude $10^{\circ} 15^{1}$ and longitude $13^{\circ} 15^{\prime}$ is the second largest town in Adamawa state in Nigeria. It has a water treatment plant, which has a capacity of pumping $480 \mathrm{~m}^{3}$ of water per hour. This plant is not operating at its full capacity due to problems including inadequate power supply (Medugu and Malgwi, 2005), irregular supply of diesel and chemicals from the headquarters, sedimentation of the dam in raining season and poor pipe network. Majority of the residents depend on water vendors for their daily water need. These vendors hawk water along all the major streets in Mubi obtained from a borehole at the bank of river Yedzeram located in Kolere and Nassarawa wards. Hawked water is also liable to contamination. These factors prompted the emergence of this study.

\section{Basic Theory on Performance Prediction}

The performance of a solar still is commonly expressed as the measure of water produced by each unit of the basin area in a day, such as, cubic metres or litres per square metre of the basin area per day. The amount of distillate depends on the design of the still, intensity of solar radiation and the atmospheric condition in the surrounding (Sayigh, 1977).

Usually, the transparent glass cover, water and basin liner absorbs the incoming radiation with a small fraction of it being reflected back to space by the glass and water surfaces. The absorbed energy in the basin available to produce vapour, and hence distillate, depends on the temperature change of the basin water and on the heat losses from the water basin. Consequently, the heat and mass transfer to the transparent glass cover on the inside coupled with the rate of heat dissipation from the cover on the outside will greatly affect the amount of vapour condensed, and hence the quantity of distillate produced.

Heat flux relations in solar still (Sayigh, 1977) for several conditions are as follows:

\section{Heat balance on basin water}

$$
\alpha w \tau H=q_{b}+C_{w b}\left(d T_{w} / d t\right)+q_{e}+q_{r}+q_{c}
$$

where $\mathrm{a}_{\mathrm{w}}=$ absorbtivity of water to radiation; $\mathrm{C}_{\mathrm{wb}}=$ heat capacity of water basin and contents per unit area; $\mathrm{H}=$ solar radiation flux on a horizontal surface; $T_{w}=$ water temperature; $\tau=$ time constant; $\mathrm{t}=$ time; $\mathrm{q}_{\mathrm{b}}=$ heat flux, still basin to grounds and surroundings; $\mathrm{q}_{\mathrm{e}}=$ heat flux by evaporation/condensation, water surface to transparent cover; $\mathrm{q}_{r}=$ heat flux by radiation, 
water to cover; and, $\mathrm{q}_{\mathrm{c}}=$ heat flux by convection, water surface to transparent cover.

$$
\mathrm{q}_{\mathrm{e}}+\mathrm{q}_{\mathrm{r}}+\mathrm{qc}+\mathrm{a}_{\mathrm{g}} \mathrm{H}=\mathrm{q}_{\mathrm{ga}}+\mathrm{C}_{\mathrm{gs}}\left(\mathrm{dT}_{\mathrm{g}} / \mathrm{dt}\right)
$$

where $a g=$ absorbtivity of transparent cover for radiation; $\mathrm{qga}=$ heat flux, transparent cover to air; $\mathrm{C}$ gs $=$ heat capacity of transparent cover and support per unit of basin area; and, $\mathrm{Tg}=$ temperature of transparent cover.

\section{Heat balance on basin and cover assembly}

$$
\mathrm{agH}+\alpha w \tau \mathrm{H}=\mathrm{q}_{\mathrm{ea}}+\mathrm{q}_{\mathrm{b}}+\mathrm{C}_{\mathrm{wb}}\left(\mathrm{dT} \mathrm{T}_{\mathrm{w}} / \mathrm{dt}\right)+\mathrm{C}_{\mathrm{ss}}(\mathrm{dTg} / \mathrm{dt})(3)
$$

These equations are formulated so that the reflected short-wave radiation does not appear in them since it has no effect on vapour formation or condensation (Sayigh, 1977).

\section{Materials and Method}

Materials used for the construction of the designed solar still, shown in fig. 1, are plastic, black paint, transparent glass, headlamp gum wood and taps. Records of monthly mean dily sunshine data for Mubi, Adamawa State, from April 2004 to December 2005 is presented in Tabiei. The data was obtained from Department of Geography, Adamawa State University, Mubi. They were used to confirm the continuous availability of sunshine enough to supply solar energy to the designed solar still.

A total of three wards, whose source of drinking water are boreholes were chosen as sample area. They are Kolere, Nassarawa and Wure Gude wards. Twenty-four water samples $\mathrm{r}$;re collected from the various boreholes in a sterile collection bottles and were transferred immediately for analysis in the laboratory.

\section{Enumeration of aerobic bacteria by aerobic piate count}

The various samples were mixed by shaking. $1.0 \mathrm{ml}$ of each sample was pipette into a tube containing $9.0 \mathrm{ml}$ of the buffered peptone water. $1.0 \mathrm{ml}$ of the first dilution was transferred to second dilution tube containing $9.0 \mathrm{ml}$ of the buffered peptone water and sample was mixed with a fresh pipette. $1.0 \mathrm{ml}$ of the second dilution was transferred to the third dilution tube containing $9.0 \mathrm{ml}$ buffered peptone water. The water samples were diluted three-fold serially. $1.0 \mathrm{ml}$ of each dilution of water sample was inoculated into appropriately marked duplicate nutrient agar plates. The plates were incubated at $30^{\circ} \mathrm{C}$ for 36 hours. The resulting bacterial colonies were observed and viable microbial count was done using colony counter each as equal to Number Colonies x Dilution Factor (cfu).

\section{Enumeration of coli form by multiple-tube fermentation technique \\ Presumptive test}

Three tubes of the single-strength lactose broth were inoculated with $0.1 \mathrm{ml}, 1 \mathrm{ml}$ and $5 \mathrm{ml}$ water samples. All tubes were incubated at $35^{\circ} \mathrm{C}$ for 36 hours. The lactose broth tubes were observed for gas production after 24 hours.

\section{Confirmatory test}

Tubes showing positive presumptive test were used to streak eosine methylene blue agar plate. The plates were incubated at $35^{\circ} \mathrm{C}$ for 24 hours. Plates were observed for coli form colonies.

\section{Completed test}

Confirmed coli form colonies were used to inoculate a tube of lactose broth with durham tube. The tubes were incubated at $35^{\circ} \mathrm{C}$ for 36 hours. The lactose broth culture was observed for gas production.

\section{Description of the Solar Still}

The designed solar still as shown in fig. 1 , consists of a shallow triangular plastic basin. The inner bottom of the plastic is painted black in order to absorb sun's heat effectively. The top of the basin is covered with transparent glass tilted to the angle of latitude of Mubi, $10^{\circ} 15^{1}$, to ensure maximum transmission of solar radiation into the still as well as enabling condensed vapour to trickle down the trough built in the still basin. The edges of the glass are sealed with headlamp gum so that the entire basin becomes airtight. The entire structure is made of quality materials designed to withstand the harsh conditions produced by water and sunlight and it is placed on a wooden stand. The design incorporates a supply fill port through which water is added into the still. Purified drinking water is collected from distilled output collector. There is an overflow port, which will flow out excess water in the still.

\section{Operation of the solar still}

The tilted glass face is adjusted to the latitude of Mubi. The contaminated water is poured into the still to partially fill the basin through supply fill 


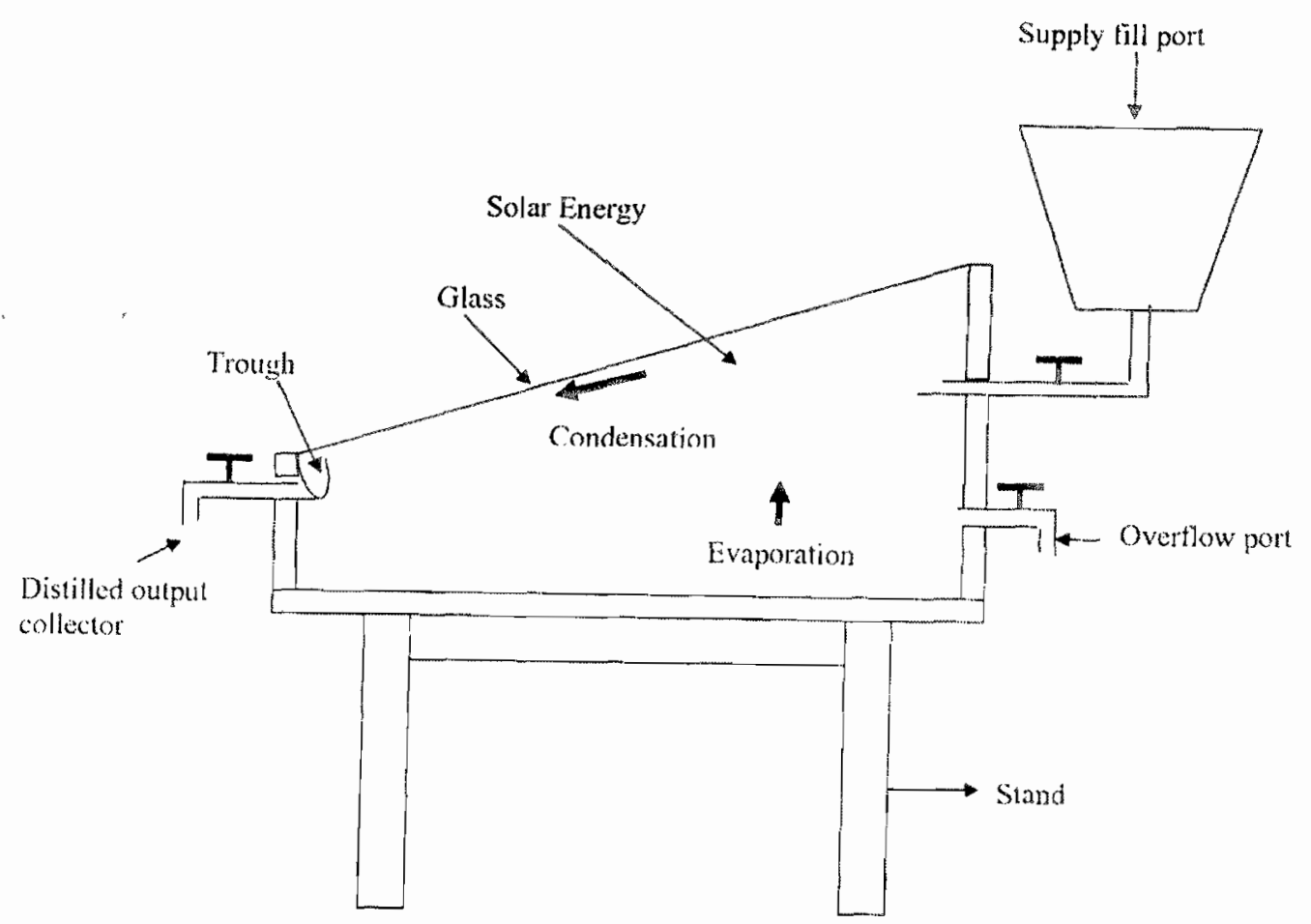

Fig. 1: Orthographic projection of the solar still

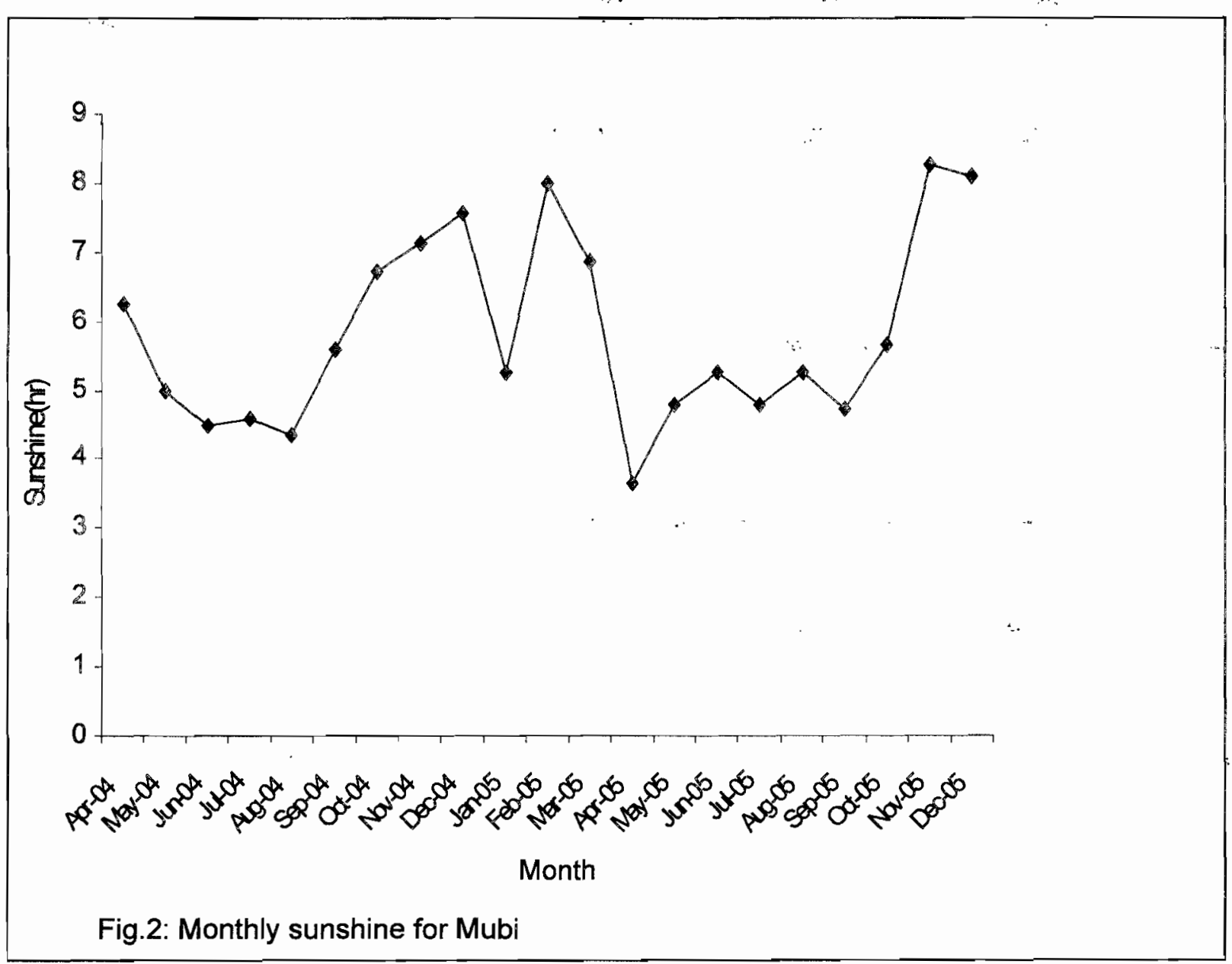


port. Care was taken in adding the water at a slow enough rate to prevent splashing onto the interior of the still glazing or overflowing into the collection trough. The glass cover allows the solar radiation (short wave) to pass into the still, which is absorbed effectively by the blackened base. Temperature of the water increases and the moisture content of the air trapped between the water and the glass cover increases. The base also radiates energy in the infrared region (long wave) which is reflected back into the still by the glass cover, trapping the solar energy inside the still (the 'greenhouse' effect). Water vapor rises upward and condenses on the inner surface of the glass cover, which is relatively cold. In this process, the salts and microbes that were in the original water are left behind. Condensed water vapor trickles down the inclined glass cover to an interior collection trough from there it is collected into the storage container through distilled output collection port.

\section{Results and Discussion}

The monthly mean daily sunshine data for Mubi, Adamawa state from April, 2004 to December, 2005 as presented in Table1 were obtained from Department of Geography, Adamawa State University, Mubi. The monthly average sunshine in Mubi is $5.72 \mathrm{hr} \pm 0.01 \%$. From Figure 1 , minimum and maximum sunshine so far recorded are $3.27 \mathrm{hr}$ and $8.26 \mathrm{hr}$ respectively. These are adequate for operation of any solar equipment especially solar still.

Almost all residences of Mubi rely on borehole for clean source but unfortunately, from the analysis carried out in Table1, it was observed that the boreholes in Mubi are heavily contaminated with an average microbial load of $2.57 \times 10^{4} \mathrm{mg} / \mathrm{l}$. It was also observed that the samples of the borehole water were positive with $100 \%$ distribution of coli form bacteria with an average of $266.7 \mathrm{mg} / 1$ and 7.83 of $\mathrm{CaCO}^{3}$ and $\mathrm{pH}$ value respectively.

The effectiveness of the constructed solar still is tested by introducing the samples of the contaminated boreholes water into the designed still and, it was observed that it is capable of removing the salts as well as the biological contaminants. The efficiency of the still is typical of any standard solar still as it produces 9liters of portable water per day in temperate climate. The solar still has proven to be highly effective in cleaning up water supplies to provide safe drinking water. This solar distillation technology produces the same safe quality drinking water as other distillation technologies; only that the energy source is different (solar) for producing clean drinking water.

Table 1: Monthly mean daily sunshine data for Mubi.

\begin{tabular}{|l|l|l|}
\hline Month & Year & Sunshine(hr) \\
\hline April & 2004 & 6.25 \\
May & 2004 & 5.00 \\
June & 2004 & 4.50 \\
July & 2004 & 4.58 \\
August & 2004 & 4.34 \\
September & 2004 & 5.59 \\
October & 2004 & 6.71 \\
November & 2004 & 7.13 \\
December & 2004 & 7.56 \\
January & 2005 & 5.25 \\
February & 2005 & 7.98 \\
March & 2005 & 6.85 \\
April & 2005 & 3.65 \\
May & 2005 & 4.78 \\
June & 2005 & 5.26 \\
July & 2005 & 4.73 \\
August & 2005 & 3.27 \\
September & 2005 & 4.73 \\
October & 2005 & 5.64 \\
November & 2005 & 8.26 \\
December & 2005 & 8.08 \\
\hline
\end{tabular}


Table2: Water quality tests conducted in Mubi.

\begin{tabular}{|l|l|l|c|}
\hline Test & Location & Input & Output \\
\hline Aerobic bacterial count (cfu/ml) & Kolere & 2.10 & 4 \\
& Nassarawa & 3.20 & 0 \\
& Wuro Gude & 2.40 & 4 \\
\hline Distribution of coli form bacteria (\%) & Kolere & $100 \%$ & 0 \\
& Nassarawa & $100 \%$ & 0 \\
& Wuro Gude & $100 \%$ & 0 \\
& Kolere & 260 & 0 \\
\hline $\mathrm{CaCO}_{3}(\mathrm{mg} / \mathrm{l})$ & Nassarawa & 280 & 0 \\
& Wuro Gude & 260 & 0 \\
\hline $\mathrm{pH}$ & Kolere & 7.8 & 0 \\
\hline & Nassarawa & 7.9 & 9.1 \\
& Wuro Gude & 7.8 & 9.2 \\
\hline
\end{tabular}

$\mathrm{Cfu} / \mathrm{ml}$ : Colony forming unit per $\mathrm{ml}$

\section{Conclusion}

Over one billion people in the world do not have access to portable water. One area in Nigeria with problematic water needs is Mubi in Adamawa State. Almost all the residences of the town rely on borehole water but unfortunately, this research work reveals that they are contaminated. The water is also re-contaminated during hawking which presents a significant health risk. Consequently, solar still has been constructed and is a proven concept for providing portable water since it was first conventionally utilized in Chile in 1872 (Sobsey, 2002; WHO, 2000; Walter, 1987). The solar still which operates on the same principle as rainwater- evaporation and condensation process, is an innovative, effective, simple, and decentralized on site water treatment system that can provide safe water in a cost effective and reliable manner.

\section{References}

Cooper, R.I. (1969): The Absorption of Solar Radiation in Solar Stills, Sol. Energy 12 (3), 333

Frohlich, C. and Brusa, R.W. (1981): Solar Radiation and it Variation in Time, Sol. Phys; 74, 209-215.

Garba, B., Eboatu, A.N. and Sambo, A.S. (1999): The Solar Energy Option, Newly Popular Series Book 3, Sokoto Energy Research Centre pp. 88.
Gunnison, D. (1985): Microbial Processing In Reservoirs, Dordrecht: Dr. W. Junk Publishers, 79- 92.

Malgwi, D.I. (2006): Energy and Environmental Physics. Postgraduate Lecture Notes (Unpublished), University of Maiduguri, 65.

Medugu, D.W. and Malgwi, D.I. (2005): A Study of Wind Energy potential: Remedy for fluctuating Electric Power in Mubi, Adamawa State, Nigeria. Nig. Journ. of Physics Vol 17., 40.

Sayigh, A.A.M. (1977): Solar Energy Engineering. New York: Academic Press Inc., 431-464.

Sanyaolu, B.O., Malgwi, D.I. and Mashauri, D.A. (2002): Performance Evaluation of some Natural Fibers for Slow and Sand Filter Protection. African Journ. Environmental Poll. \& Health 2:61-66.

Sobsey, M.D. (2002): Managing Water in the Home: Accelerated Health Gains from Improved Water Supply, Chapel Hill, North Carolina, USA.

Smith, E.V.P. and Gattlieb, D.M. (1974): Solar Flux and its Variation. Space Sc. Rev. 16, 771-802. 
Uwah, I.E. Ibok, U.J., Ekpe, U.J., and Etiuma, R.A. (2004): Comparative Study of Rainwater Quality at Iko, Etche and Calabar, S.E. Nigeria. African Journ. Enviromental Poll. \& Health $3(1), 1-5$.

Walter, L. (1987): Hand book of water purification, $2^{\text {nd }}$ Edition, New York: Ellis $\mathrm{Harwood}$ Limited, 153-154.

WHO (2000): Water, Sanitation and Health Department of Protection of the Human Environment. World Heal Organization, Geneva. 